\title{
Johnson neuroectodermal syndrome
}

\author{
INSERM
}

\section{Source}

INSERM. (1999). Orphanet: an online rare disease and orphan drug data base. Johnson neuroectodermal syndrome. ORPHA:2316

Johnson neuroectodermal syndrome is characterised by alopecia, anosmia or hyposmia, conductive deafness with malformed ears and microtia and/or atresia of the external auditory canal, and hypogonadotropic hypogonadism. 